\title{
An Overview of Domestic Work Phenomenon
}

\author{
Kola O. Odeku \\ Faculty of Management and Law, School of Law, \\ University of Limpopo, South Africa \\ Email:kooacademics@gmail.com
}

Doi:10.5901/mjss.2014.v5n9p697

\begin{abstract}
One of the fastest growing informal vocations in the world is domestic work. It is usually performed by women from developing countries living in developed or developing countries. They work for the affluent and middle class career women and men. Domestic work raises a lot of controversial issues and concerns. While some argue that it is a deserving work that should be performed, others see it as a dirty work reserved for uneducated illiterates. By and large, the general consensus is that it is a form of employment hence the rights and dignities of those who engage in it should be protected under the labour law and the law of the land like other vocations and careers. This paper looks at the dynamics of domestic work and numerous interventions that have been put in place to accord it the dignity and right it deserves. It accentuates that in view of the fact that those who engage in it are vulnerable women and children, the protective mechanisms could only be meaningful and produce the expected results if they are closely implemented and monitored.
\end{abstract}

Keywords: Domestic Labour, Employment, Regulations, Protection, Householders, Maids.

\section{Introduction}

Domestic work is widespread and thriving worldwide and it is now an international phenomenon (Anderson, 2000). Nowadays, scores of women from poor countries make the difficult choice to leave their families behind and risk the hazardous journeys that brings them, either legally or illegally to the shores of rich countries to work as domestic workers (Ally, 2011). In South Africa, majority of the domestic workers live in informal poor settlements like townships, locations and shacks very far away from where their employers live and they have to resume work every morning by literally moving across the boundaries of race and class to get to work on a daily basis in order to do the dirty works that keep the masters and the madams' households functioning and secure (Ally, 2011). In South Africa, The Department of Labour has indicated that domestic work is dominated by black women predominantly Africans and coloured (Du Toit, 2010). The International Labour Organisation Report (ILO) of 2010 revealed that domestic workers are undervalued and treated poorly and they remain overworked, underpaid, maltreated, abused, intimidated, threatened and unprotected. Du Toit (2010) puts it this way "describing the different worlds inhabited by white women and their black female servants, the book developed a paradigm of the domestic employment relationship which to a large extent remains valid today: a relationship which is liberating for the (white) employer but exploitative of the (black) employee, even though both are women experiencing the general oppression of women, but in vastly different ways." They are also subjected to various maltreatments and abuses, especially those that live-in the homes of the masters and the madams. Migrant domestic workers are intimidated as employers use deportation and arrest to threaten them (Scully, 2009). What is worrying and disturbing is that domestic work is also being performed by children (White, 2001). The research conducted on socioeconomic conditions of the workers on behalf of the Services Sector Education and Training Authority which was presented to the International Labour Organisation (ILO) conference in 2010 revealed damning evidence of the abuse of domestic workers by South African's middle and upper class (Motala, 2010). However, it is important to point out that while South Africans citizens who work as domestic workers have become more sensitised and are able to stand for their rights in negotiating wages and resisting unfair labour practice, the migrant workers looking for same job is ready and willing to accept maltreatments, low wages hence the employers usually hire them (Jain et al. 2003). This has serious implication on the effective application of the legislation and the conditions of employment of South African domestic workers. They are being seriously undermined by these economic migrants who are ready to work under any condition for the employers (Munakamwe, 2009). Consequently, as a result of this alternative, employers are using the threat of employing vulnerable foreign migrants as a way of keeping wages low for South African domestic workers (Zuberi and Sibanda, 2004). Therefore, desperate poor South African domestic workers will yield to the threat and succumb to being 
subjected to poor working conditions under which they are forced to work long hours, for minimum or less than minimum wages and become vulnerable to exploitation and abuse (Grub, 2006). Du Toit (2010) has pointed out that the "conditions of employment in the domestic sector are generally poor and often very poor, in the worst cases amounting to servitude rather than employment."

Despite legislative interventions, domestic workers are still vulnerable, timid, and intimidated as they sometimes abandon their human and labour rights for fear of reprisals and dismissal in order to stay on the job (Ally, 2008).

The rate at which employers dismiss domestic workers with impunity is appalling in South Africa (Kriger, 2007). Although labour remedies like reinstatement, re-employment and compensation are available to domestic workers, in most cases, they chose not to seek redress and invoke their entitled rights to fair labour practice and right to dignity when they are unfairly dismissed (du Toit, 2013). To this end, a lot of employers of domestic workers walk away without being brought to justice (Macklin, 1991). The huge challenge is that most of the domestic workers are poor illiterates and are not aware of the protective mechanisms available to them under the laws even though they fall under the definition of employees under the labour law (Shelley, 2007).

This notwithstanding, the important issue is that in the current democratic South Africa, there have been extensive efforts by the government to bring domestic workers within the ambits of the protective mechanisms in laws and labour laws like any other works (Fish, 2006). They can exercise all the rights that a worker has under the law in South Africa without any restriction whatsoever (Ally, 2008). Relying on empirical data, the study conducted by Fish (2006) revealed that "drawing upon 85 interviews and extensive field research, this article explores how domestic workers have collectively organised through unionisation and coalition-building to restructure the apartheid legacies contained within this institution. By aligning with South Africa's Gender Machinery, the South African Domestic Service and Allied Workers' Union realised pivotal social security policy change through the first formal inclusion of the domestic work sector in unemployment insurance. This legislative victory emphasises the importance of engendering democracy at both the public and private levels to enhance the accessibility of women's rights, particularly within this isolated and highly gendered labour sector" (Fish, 2006).

\section{Literature Review}

According to Yeoh (2004) "there is a growing literature on how the globalisation of paid domestic workers means that hundred of thousands of women from poor countries in the global South are living in the form of servitudes, as of a "global care chain."

In South Africa, the enactment of Sectoral Determination Seven of the Labour Relations Act has introduced domestic workers for the first time into the fairness provisions of labour legislation and this has fundamentally changed the relationship between householder and domestic worker (Benjamin et al. 2010). The enactment of the law brings absolute protection to domestic workers against discrimination and unfair dismissal (Blackett, 2011). The householders are therefore obligated to comply with the law otherwise they shall face the consequences for violation and breach of the law (Durrheim et al. 2013). The law reiterated and confirmed that the relationship between domestic workers and their employers was first regulated in January 1994 when domestic workers were included in the ambit of the Basic Conditions of Employment Act, which set out rules relating to hours of work, overtime, sick leave, annual leave and more (Nilliasca, 2010). By including domestic workers in the Labour Relations Act, domestic workers now have locus standi to contest the contractual violations of their employment relationships as well as the fairness of any violation (Mubangizi, 2004). The householders are therefore expected to be fair and responsible in the ways and manners they act and treat their workers (Momsen, 1999). If there is any reason for termination, it should be on reasonable grounds recognised under the labour law such as misconduct, incapacity, poor work performance, ill health or injury and retrenchment which could be sustained only in cases where you move town or country. More importantly, for there to be a valid and effective termination of employment, the domestic worker is entitled to a hearing (Bhorat et al. 2009).

It is therefore important to point out that failure to comply with the dismissal procedures prescribed by the Act will attract appropriate sanctions and the employer will be compelled to pay compensation for unfair dismissal by the appropriate labour tribunal-the Commission of Conciliation, Mediation and Arbitration (CCMA) ( Tsogas, 2001). The CCMA has the power to order reinstatement as a remedy for unfair dismissal as stated in the Act, however, with regard to situations of dismissed domestic workers, compensation is more likely to be ordered and thereafter, the worker can as well look for another suitable job (Grogan, 2007). The compensation will assist to sustain her while looking for another job and it also serves as an indication to upholding of the right to fair labour practice (Holley et al. 2011). As a sanction, compensation will serve as deterrence to the employer from treating or acting unfairly to the worker (Roberts, 2005). Therefore, there are a whole lot of situations that fall within the ambit of unfair dismissal of domestic worker under the Act 
(Benjamin, 2008). The householder who dismisses a domestic worker for being pregnant will be acting in contravention of the Act (Bannan, 2011). Similarly, it will also be a contravention of the Act if the domestic worker takes time out to go and fetch her child in school or from care giver (du Toit and Huysamen, 2013). These examples and other situations that are similar to these might be regarded as unfair dismissals ( Youngblood et al. 1992).

Domestic work is an informal employment and according to ILO "informal employment is a key challenge in today's globalized economies, not only from the perspective of millions of women and men who earn their livelihoods working and producing under informal arrangements, but also for policy-makers striving to find the right policy responses. Typically, those in the informal economy earn little and have low productivity, in spite of working long hours. Exposed to inadequate and unsafe working conditions, they also have limited access to social protection and weak coverage under the law, and are often not unionized" (ILO, 2014).

It is therefore imperative to ensure that domestic workers know their rights and how to claim them as entitlements in view of the fact that the South African legal system and laws recognise them (Landau, 2006). Being a casual or domestic worker does not limit the enjoyment of these protected labour rights (Thurman and Trah, 1990). Domestic workers are to be treated fairly by the people they work for, whether it is for one day a week or every day of the working week (Katzman, 1981). These laws frown against unfair labour practices. The Basic Conditions of Employment Act 1997, Sectoral Determination 7: Domestic Worker Sector 2002, section 1 defines a domestic worker as an employee whose job is wholly or mainly to do domestic work in a dwelling that a household uses mainly to live in (Ntisa, 2013). Gardeners, people employed as drivers of motor vehicles, and people who take care of children, the aged, the sick, and the disabled also fall within the Act's definition of domestic workers.

The definition of a "Domestic Worker" is any worker or independent contractor who performs domestic work in a private household and who receives, or is entitled to receive pay and includes

a) a gardener;

b) a person employed by a house hold as a driver of a motor vehicle; and

c) a person who takes care of children, the aged, the sick, the frail or the disabled;

d) domestic workers employed or supplied by employment services.

The ILO's International Standard Classification of Occupations (ISCO, 1987) "is one of the main international classifications for which ILO is responsible. It belongs to the international family of economic and social classifications. ISCO is a tool for organizing jobs into a clearly defined set of groups according to the tasks and duties undertaken in the job. Its main aims are to provide:

- a basis for the international reporting, comparison and exchange of statistical and administrative data about occupations;

- a model for the development of national and regional classifications of occupations; and

- a system that can be used directly in countries that have not developed their own national classifications" (ISCO, 1987). It recognizes domestic work under two broad classification groupings and identifies associated tasks and the corresponding skill levels" (ISCO, 1987).

Irrespective of the groupings, the common denominator that is applicable to all is that no one should be subjected to unfair labour practice (Posner and Nolan, 2003). And as such, as employees, domestic workers are entitled to full protection of the law (Ramirez-Machado, 2003). The ILO (2011) explicitly provides for this in article 3 thus "1. Each Member shall take measures to ensure the effective promotion and protection of the human rights of all domestic workers, as set out in this Convention.

2. Each Member shall, in relation to domestic workers, take the measures set out in this Convention to respect, promote and realize the fundamental principles and rights at work, namely:

- (a) freedom of association and the effective recognition of the right to collective bargaining;

- (b) the elimination of all forms of forced or compulsory labour;

- (c) the effective abolition of child labour; and

- (d) the elimination of discrimination in respect of employment and occupation."

\section{Recent Trends in Domestic Work Phenomenon}

The issues surrounding domestic work phenomenon have attracted overwhelming attention in international discourse and arena (Romero, 1998) and "recognizing the significant contribution of domestic workers to the global economy, which includes increasing paid job opportunities for women and men workers with family responsibilities, greater scope for caring for ageing populations, children and persons with a disability, and substantial income transfers within and between 
countries," (ILO, 2011). On 16 June 2011, a set of international labour standards (The new ILO standards) provide that domestic workers around the world who care for families and households, must have the same basic labour rights as those available to other workers: (Shah and Seville, 2012) such as reasonable hours of work, weekly rest of at least 24 consecutive hours, a limit on in-kind payment, clear information on terms and conditions of employment, as well as respect for fundamental principles and rights at work including freedom of association and the right to collective bargaining on decent work for domestic workers were adopted by the International Labour Organization (ILO), a specialized organ of the United Nations (UN) responsible for drawing up and monitoring international labour standards (ILO, 2011). The Domestic Workers Convention No 189 and the Domestic Workers Recommendation No 201 are the first set of international standards that establish a comprehensive legal framework specifically regulating the working life of domestic workers (Mantouvalou, 2012). The aim of these new instruments (Domestic Workers Convention 2011 (No. 189) and Domestic Workers Recommendation No. 201) is to improve the working conditions of millions of domestic workers by setting minimum standards of employment for this occupational group (Johnstone, 2012).

The ILO Convection recognised that domestic workers are persons who work, sometimes as live-in, in the homes of individuals providing services such as cooking, cleaning and taking care of children, in return of remuneration (Ramirez-Machado, 2003; Lutz, 2002). An overwhelming majority of domestic workers are women and girls, mostly migrant workers (Hondagneu-Sotelo, 2007). The vast majority of domestic workers are from the poorer sections of the society (Chang and Ling, 2000).

In South Africa, formal legal recognition was accorded to domestic workers in 1998 and they became entitled to legislative rights such as notice period and termination of employment, minimum wage, hours of work and so on (Ntisa, 2013). In theory, the law has improved the legal status of domestic workers, this is so because there are number of provisions and rights that the state provided for the domestic workers by including domestic workers in the existing laws and policies that protect the rights of workers and to recognise domestic work as a form of employment (Gaitskell, 1983). However, domestic workers are still treated poorly by employers notwithstanding the democratic changes in South Africa (Wessels, 2009).

In 1993, the provisions of the Basic Conditions of Employment Act in section 35 were extended to cover domestic workers in order to ensure that their working conditions are regulated just like any other work (Ramirez-Machado, 2003).

Nowadays, domestic workers are protected from sexual harassment by the Labour Relations Act, and they can also benefit from the available social security benefits such as maternity leave benefits and unemployment insurance (Cooke, 2010). The treaty seeks to emancipate domestic workers from abuses, bondage and ensure they are guaranteed the same rights as other workers (Rassam, 2004). The explicit promotion and protection of fundamental human rights clearly indicate that domestic workers are to be treated with dignity and respect their labour rights. It contains provisions that promote and protect the human rights of domestic workers (Alston, 2004), as well as fair terms of employment and decent living condition of domestic workers (Taran and Geronimi, 2003). However, considering the realities of the domestic workers in the bosses' homes, their circumstances have not been influenced by the numerous interventions put in place to ensure decent works and as such their circumstances have not changed. Most of the domestic workers still face unfair labour practice because they are desperate for work as other jobs might be difficult to get as they are illiterates (Wessels, 2009).

The publication of the Sectoral Determination 7: Domestic Workers Sector 2002 was a milestone to improve labour conditions for domestic workers and its application has, to a reasonable extent been yielding positive fruits but much more still needs to be done in the areas of strengthening the laws on the improvement of conditions of domestic workers (More-Hollerweger and Meyer, 2010).

\section{Challenges}

The issues of the conditions the domestic workers work in their employers houses are no more isolated phenomenon of marginal interest to both the local and international communities (Yeoh, 2004).

Fish (2006) argues that "though domestic workers comprise one of the largest sectors of working women, their location in private households poses severe obstacles to formalising this particular labour. In the South African case, domestic work continues to reinforce social constructions of the household as a feminised and racialised space, through the paid labour of black women. While domestic workers face severe marginalisation as a result of continuing social inequalities, women are also actively confronting barriers to democracy in the private employment sphere." They are predominantly black women bearing the brunt of historical disadvantage.

Similarly, inequality abounds and is clearly reflected in the works performed by domestic workers (Eichler and Albanese, 2007). In the society, they are unequally treated and sometimes shunned and looked down upon. It is pertinent 
to point out that the work they do also produce inequality which disadvantages them by not offering them opportunity to engage in prosperous, dignified valued added employments (Glenn, 2002). Rather, they make their masters prosperous while they live in perpetual abject poverty. Against this backdrop, (Ally, 2011) notes that "domestic workers crucially, make possible the paid work of their men and women they work for, subsidising the full-time incomes of their employers, displacing them for the drudgery of household work and the demands of child care."

Sometimes, it becomes a vicious circle from one generation to another serving the masters. This is explained in the context that children of domestic workers are most likely to become domestic workers themselves because of lack of education and opportunities to take them out of poverty (Parreñas, 2001). Bearing in mind that domestic workers earn meagre wages which in most cases are sufficient only to take care of feedings, thus education for the children is seen as luxury and unattainable (Mwansa, 2013). These are huge constraints and obstacles in ensuring emancipation for domestic workers. To this end, the legislative interventions will be meaningful and achieve their objectives if there are ample monitoring and enforcement. By so doing, domestic workers will be liberated and be able to break the chains of bondage and poverty by using living wages to take care of their families in order to be prosperous and successful (Johnson and Staples, 2004).

\section{To Stop or to Continue?}

There are extensive literature on the issues of domestic work and the dynamisms of the phenomenon, however, there is no single literature insisting that the work should stop or be stopped. Majority of the literature are championing the course of domestic workers locally and internationally (Lau et al. 2009). Usually, they advocate for fair labour practices toward domestic workers (Blackett, 2004). They also seek to express the views that being domestic workers does not diminish them as human beings hence they should be accorded fundamental human rights, its protective and enforcement mechanisms (Donnelly, 2013). By recognising domestic work as an employment in national and international laws, this accords the work the necessary legitimacy and validity to be treated as prescribed by the laws (Pennings, 2006). This can be achievable if equal treatment and decent work for domestic workers are mandatory and implemented (le Roux, 2013). Various scholars and the preambles to most of the instruments on domestic work recognise the significance of the contribution of domestic work to the economy and social economic upliftments of the employers (Omar and GarciaBolivar 2006). Rather than stopping it, it is therefore stressed that the abuses inherent in the work should be curtailed and stopped. Similarly, by recognising domestic work as a form of employment, it is an indication to the employers that it is not an aspect of family arrangements. It is a work duly recognised and protected under the law (Budlender, 2010).

However, in the same vein, scholars and activists have persistently been calling for the prohibition of child domestic workers (Weiner, 1996). National and international instruments prohibit child labour and slavery including trafficking (Aronowitz, 2001). There is no legal recognition of child domestic labour hence the practice is against both the national and international laws (Kanbur, 1995). It is a crime which will, if the perpetrator is caught, attract severe criminal sanction. Therefore, domestic child workers should be out rightly prohibited and condemned (Landgren, 2005).

\section{Conclusion}

Domestic work is a form of employment explicitly recognised in law and as such those who engage in and perform the work have protection like any workers. While the phenomenon is becoming increasingly widespread and thriving, there is tendency for exploitation by the employers considering the fact that it is a sort of invisible job. Pursuant to this, close monitoring is very important in order to expose abuses and unfair labour practice. While the vocation is supported and should continue because of the role it plays in the economy and the society, the inclusion and use of child domestic labour should be condemned and out rightly prohibited.

\section{Recommendations}

Extensive literature has confirmed that the work of domestic workers is contributing hugely to the productive and reproductive well-being of the society. In view of this, the status of the job should be enhanced and uplifted by properly remunerating those who discharge these invaluable responsibilities.

The employer is under legal obligation to treat domestic workers as prescribed by the law. One of such obligations is to ensure that they too are part of the stride to emancipate domestic worker by providing them with conditions of employment as enshrined in the labour law. Considering that majority of the domestic workers are illiterates, while unions and labour rights advocates are providing them with knowledge of the rights they have as employees, the employers 
should come to the party by also lending hands in making frantic efforts to ensure that they sensitise and teach them their rights under the law. These will include paying them living wages, refraining from unfair labour practice and upholding of fundamental human rights.

With regard to domestic child workers, ample free education should be afforded them and governments and institutions should ensure that they have their ears on the ground in order to gather information on wherever or whoever is using a child as domestic labour. This will become realisable and achievable if the support of the society and the people are enlisted.

\section{References}

Ally S 2008. Domestic worker unionisation in post-apartheid South Africa: Demobilisation and depoliticisation by the democratic state. Politgikon: South African Journal of Political Studies. 35(1): 1-21.

Alston P 2004. Core Labour Standards' and the Transformation of the International Labour Rights Regime. European Journal Of International Law, 15 (3): 457-521.

Anderson B 2000. Doing the dirty work?: the global politics of domestic labour. Zed Book Ltd, London, UK.

Aronowitz AA 2001. Smuggling and Trafficking in Human Beings: The Phenomenon, The Markets that Drive It and the Organisations that Promote It. European Journal on Criminal Policy and Research, 9(2):163-195.

Bannan NLO 2011. Domestic Workers and Their Right to be Heard: Residential Picketing Makes Visible the Invisible. A Critical Studies Journal, 4:112-121.

Benjamin P 2008. Informal Work and Labour Rights in South Africa. Industrial Law Journal, 29:1579-1568.

Benjamin P, Bhorat H, Cheadle H 2010. The cost of "doing business" and labour regulation: The case of South Africa. International Labour Review. 149(1): 73-91.

Bhorat H, Pauw K, Mncube L 2009. Understanding the Efficiency and Effectiveness of the Dispute Resolution System in South Africa: An Analysis of CCMA Data. From http://www.dpru.uct.ac.za. (Retrieved July 6, 2013).

Blackett A 2011. Introduction: Regulating decent work for domestic workers. From http://utpjournals.metapress.com/content 172742629063802q3/fulltext.pdf. (Retrieved October 10, 2013).

Bonner C 2010. Domestic Workers around the World: Organising for Empowerment. From www.dwrp.org.za/images/stories IDWRP_Research/chris_bonner.pdf. (Retrieved February 4, 2013).

Budlender D 2010. Decent work for domestic workers. From http://case.org.za/ caseorg/images/docs/domestic\%20workers.pdf. (Retrieved June 4, , 2012).

Chang KA, Ling LHM 2000. Filipina domestic workers in Hong Kong. Gender and global restructuring: Sightings. Routledge, New York, USA.

Cooke LP 2010. The politics of housework. Stanford University Press, Stanford, California.

Donnelly J 2013. Universal human rights in theory and practice. Cornell University Press, New York, USA.

Du Toit - D 2010. Extending the frontiers of employment regulation: The case of domestic employment in South Africa. Law, Democracy \& Development, 14:1-27.

du Toit D, Huysamen E 2013. Implementing domestic workers'labour rights in a framework of transformative-essential: domestic workers. Pretoria University Law Press, Pretoria, South Africa.

Durrheim K, Jacobs N, Dixon J 2013. Explaining the paradoxical effects of intergroup contact: Paternalistic relations and system justification in domestic labour in South Africa. From http://www.sciencedirect.com/science/article/pii/S0147176713001363. (Retrieved May 15, 2014).

Eichler M, Albanese P 2007. What is household work? A critique of assumptions underlying empirical studies of housework and an alternative approach. The Canadian Journal of Sociology, 32(2): 227-258.

Fish JN 2006. Engendering democracy: domestic labour and coalition-building in South Africa. Journal of Southern African Studies, 32(1): 107-127.

Fish JN 2006. Engendering democracy: domestic labour and coalition-building in South Africa. Journal of Southern African Studies, 32(1): 107-127.

Gaitskell D, Kimble J, Maconachie M, Unterhalter E 1983. Class, race and gender: domestic workers in South Africa. Review of African Political Economy, 10(27-28):86-108.

Glenn EN 2002. Unequal freedom: How race and gender shaped American citizenship and labor. Harvard College, USA.

Grogan J 2007. Dismissal, Discrimination, and Unfair Labour Practices. Juta and Co Ltd, Cape Town, South Africa.

Grub A 2006. The impact of labour legislation on South African farm workers' livelihoods in the Skuinsdrift area, North West province. From http://wiredspace.wits.ac.za/handle/10539/1800. (Retrieved January 6, 2013).

Holley W, Jennings K, Wolters R 2011. The labor relations process. Erin Joyner, Ohio, USA.

Hondagneu-Sotelo P 2007. Domestica: Immigrant workers cleaning and caring in the shadows of affluence. University of California Press, California, USA.

http://books.google.co.za/books?hl=en\&lr=\&id=Mcg7Dz9yuC4C\&oi=fnd\&pg=PP2\&dq=. (Retrieved August 23, 2013).

ILO 2010. Decent work for domestic workers. From <www2.ilo.org/public/libdoc/ilo/2009/109B09_24_engl.pdf> (Retrieved April 25, 2013). 
ILO 2010. International Labour Office. Decent work for domestic workers. From http://www.ilo.org/wcmsp5/groups/public/---ed_norm/--relconf/documents/meetingdocument/wcms 104700.pdf. (Retrieved April 19, 2013).

ILO 2014. The Informal Economy and Decent Work: A policy resource guide supporting transitions to formality. From http://www.llo.org/global/publications/books/forthcoming-publications/WCMS_223635/lang--en/index.htm. (Retrieved May 18, 2014).

ILO, 2011. C189 - Domestic Workers Convention, From http://www.ilo.org/dyn/normlex/en/f?p=NORMLEXPUB:12100:0::NO::P12100 _ILO_CODE:C189. (Retrieved October 19, 2013).

Informal Business. From http://www.bg-consulting.com/docs/informalpaper.pdf. (Retrieved November 9, 2013).

ISCO 1987. International Standard Classification of Occupations. From http://www.llo.org/public/english/bureau/stat/isco/index.htm. (Retrieved March 4, 2013).

Jain HC, Sloane PJ, Horwitz FM 2003. Employment equity and affirmative action: An international comparison. M.E. Sharpe, Incorporation, New York, USA.

Johnson LB, Staples R 2004. Black families at the crossroads: Challenges and prospects. John Wiley, California, USA.

Johnstone L 2012. Organising domestic workers: for decent work and the ILO Convention No. 189. From https://oda.hio.no/jspui/handle/10642/1764. (Retrieved May 1, 2013).

Kanbur R, Grootaert C 1995. Child Labour: An Economic Perspective. International Labour Review, 134:187-198.

Katzman DM 1981. Seven days a week: Women and domestic service in industrializing America. Oxford University Press, London, UK.

Kriger N 2007. Keep Your Head Down: Unprotected Migrants in South Africa. From

http://books.google.co.za/books?hl=en\&lr=\&id=Mcg7Dz9yuC4C\&oi=fnd\&pg=PP2\&dq=. (Retrieved August 23, 2013).

Landau LB 2006. Protection and dignity in Johannesburg: shortcomings of South Africa's urban refugee policy. Journal of Refugee Studies, 19 (3): 308-327.

Landgren K 2005. The Protective Environment: Development Support for Child Protection. Human Rights Quarterly. 27(1):214-248.

Lau PWL, Cheng JGY, Chow DLY, Ungvari GS 2009. Acute Psychiatric Disorders in Foreign Domestic Workers in Hong Kong: a Pilot Study. International Journal of Social Psychiatry, 55(6): 569-576.

Lutz H 2002. At your service madam! The globalization of domestic service. Feminist Review, 70: 89-104.

Macklin A 1991. Foreign Domestic Worker: Surrogate Housewife or Mail Order Servant. McGill Law Journal, 37: 681:692.

Mantouvalou V 2012. Human Rights for Precarious Workers: The Legislative Precariousness of Domestic Labor. Comparative Labour \& Policy, 34: 133-142.

Momsen JH 1999. Gender, migration and domestic service. Routledge, London, UK.

More-Hollerweger E, Meyer M 2010. Work and Employment in the Nonprofit Sector. From http://link.springer.com/referenceworkentry 110.1007/978-0-387-93996-4_632\#.(Retrieved September 4, 2013).

Motala M 2010. Mohamed Motala. Domestic Workers in South Africa: It's Modern Day. From http://www.sacsis.org.za/site/article/473.1. (Retrieved November 29, 2013).

Mubangizi JC 2004. The protection of human rights in South Africa: A legal and practical guide. Juta and Company Ltd, Cape Town, South Africa.

Munakamwe J 2009. Challenges in organising informal workers: a study of gendered home-based care work in post-apartheid South Africa. http://mobile.wiredspace.wits.ac.za/handle/10539/6583. (Retrieved June 9, 2013).

Mwansa SMV 2013. The experiences and working conditions of domestic workers in Lusaka Zambia. From http://wiredspace.wits.ac.za/handle/10539/13299. (Retrieved May 2, 2014).

Nilliasca T 2010. Some Women's Work: Domestic Work, Class, Race, Heteropatriarchy, and the Limits of Legal Reform. Michigan Journal of Race \& Law, 16:377-389.

Ntisa AA 2013. Contract of employment and its impact on the job security of domestic workers. From http://196.21.64.68/handle/10352/127. (Retrieved April 24, 2014).

Ntisa AA 2013. Contract of employment and its impact on the job security of domestic workers. http://196.21.64.68/handle/10352/127. (Retrieved January 16, 2014).

Omar E, Garcia-Bolivar 2006. Informal economy: is it a problem, a solution or both? The perspective of the informal business. From http://www.bg-consulting.com/docs/informalpaper.pdf. (Retrieved November 9, 2013).

Parreñas RS 2001. Servants of globalization: Women, migration and domestic work. Stanford University Press, California, USA.

Pennings F 2006. Between soft and hard law: the impact of international social security standards on national social security law. Kluwer Law International, Hague, Netherlands.

Posner M, Nolan J 2003. Can codes of conduct play a role in promoting workers' rights? Stanford University Press, California, USA.

Ramirez-Machado JM 2003. Domestic work, conditions of work and employment: A legal perspective. From http://www.ilo.int/wcmsp5 Igroups/public/---ed_protect/---protrav/---travail/documents/publication/wcms_travail_pub_7.pdf. (Retrieved December 16, 2012).

Rassam AY 2004. International Law and Contemporary Forms of Slavery: An Economic and Social Rights-Based Approach. Pennsylvanian State International Law Review, 23: 809-821.

Roberts JC 2005. Injustice and rectification. Peter Lang Publishing, Incorporation, New York, USA.

Romero M 1998. Immigration, the Servant Problem, and the Legacy of the Domestic Labor Debate: Where Can You Find Good Help These Days. University of Miami Law Review, 53:1045-1056.

Scully K 2009. Blocking Exit, Stopping Voice: How Exclusion from Labor Law Protection Puts Domestic Workers at Risk in Saudi Arabia and around the World. Columbia Human Rights Law Review, 41:825-834. 
Shah H, Seville V 2012. Domestic Worker Organizing: Building a Contemporary Movement for Dignity and Power. Albany Law Review, 75: 413-421.

Shelley T 2007. Exploited: migrant labour in the new global economy. Zed Books, Ltd, New York, USA.

Taran PA, Geronimi E 2003. Globalization, labour and migration: Protection is paramount. From http://www.cepal.cl/celade/noticias /paginas/2/11302/PTaran.pdf. (Retrieved November, 16, 2012).

Thurman JE, Trah G 1990. Part-Time Work in International Perspective. International Labour Review, 129:23-34.

Tsogas G 2001. Labor regulation in a global economy. M.E.Sharpe Inc, New York, USA.

Weiner M 1996. Child labour in India: putting compulsory primary education on the political agenda. Economic and Political Weekly, 31(45/46):3007-3014.

Wessels TS 2009. The development impact of the domestic workers skills development project on its participants. From http://uir.unisa.ac.za/handle/10500/1720. (Retrieved December 4, 2013).

White SC 2001. From the politics of poverty to the politics of identity? Child rights and working children in Bangladesh. Journal of International Development, 14(6): 725-735.

Yeoh BSA, Huang S, \& Devasahayam TW 2004. Diasporic subjects in the nation: Foreign domestic workers, the reach of law and civil society in Singapore. Asian Studies Review, 28(1): 7-23.

Youngblood SA, Trevino LK, Favia M 1992. Reactions to unjust dismissal and third-party dispute resolution: A justice framework. Employee Responsibilities and Rights Journal, 5(4):283-307.

Zuberi T, Sibanda A 2004. How Do Migrants Fare in a Post-Apartheid South African Labor Market? International Migration Review. 38(4): 1462-1491. 